\title{
NO TEATRO DO HERÓI SURRADO: NOTAS SOBRE OS EXERCÍCIOS DE CRÍTICA NOS ESCRITOS DE BRECHT E BENJAMIN
}

\author{
Wanderson Barbosa dos Santos
}

\begin{abstract}
RESUMO
Este ensaio visa destacar as afinidades eletivas entre o pensamento de Bertolt Brecht e Walter Benjamin. Percorrendo ensaios, peças teatrais e documentos, analisaremos ao longo do texto questões como o engajamento intelectual, o exercício da crítica da sociedade e a relação entre arte a política. Nesse sentido, partindo de uma análise do teatro épico brechtiano apresentaremos os contornos desse empreendimento de arte engajada. A seguir, apontaremos as afinidades entre o teatro épico e o que Benjamin chama de teoria do escritor progressista.
\end{abstract}

Palavras-chaves: Teatro épico. Escritor progressista. Crítica. Engajamento. Arte. Política.

\section{AT THE THEATER OF THE BATTERED HERO: NOTES ON THE EXERCISES OF CRITICISM IN THE WRITINGS OF BRECHT AND BENJAMIN}

\begin{abstract}
This essay aims to highlight the elective affinities between the thinking of Bertolt Brecht and Walter Benjamin. Through essays, plays and documents, we will analyze issues such as intellectual engagement, the exercise of society's criticism and the relationship between art and politics. In this sense, starting from analysis of the Brechtian epic theater, we will present the contours of this engaged art enterprise. Next, we will point out the affinities between epic theater and what Benjamin calls the progressive writer's theory.
\end{abstract}

Key-words: Epic theater. Progressive writer. Criticism. Engagement. Art. Politics. 


\section{A crítica dialética da sociedade em Benjamin e Brecht}

Quem tem medo da arte? Os ruídos e reações à essa pergunta ainda ecoam no presente histórico. O barulho da inquietação fez parte do contexto social, em certa medida, das vanguardas artísticas do século XX. Embora à época o enfretamento ao status quo propiciava aos artistas o desenvolvimento de uma arte engajada nas agendas do seu tempo, na atualidade a arte engajada novamente é confrontada pelo pensamento autoritário. No palco da primeira metade do século $X X$, o front da arte crítica, se estendeu para uma atuação de exposição das contradições e das catástrofes civilizacionais modernas. Divididos pela dupla tarefa de, ora se alinhar a perspectiva da denúncia das injustiças sociais e, por outro lado, de traduzir a atmosfera de efervescência social para a experimentação estética, os artistas engajados em pautas políticas propunham em seus procedimentos situar as percepções, ideias e emoções presentes nas experiências sociais. Para esses artistas, a arte auxiliava não apenas no fomento do pensamento crítico, mas também, contribuía com a mediação entre a experiência individual e a prática coletiva.

Embora a arte muitas vezes não tenha se dedicado à atuação puramente política, a exposição das experiências sociais para os sentidos artísticos muniu a cultura, num sentido abrangente, das ferramentas para o confronto à alienação. Por essa perspectiva, se torna mais razoável compreender a quem a arte e os artistas ainda intimidam. A arte que visa a crítica da sociedade abraça os contornos políticos na medida em que se dedica à exposição das contradições sociais. Ao compor na experiência estética reflexões sobre temas como a guerra, a exploração, as divisões sociais, a injustiça, a discriminação, os artistas conseguem mediar a situação de problemas sociais para a experiência vivida do indivíduo. Dos grandes temas citados anteriormente, podem-se derivar as seguintes temáticas relativas à existência cotidiana como, por exemplo, a morte, a fome, o racismo, a insegurança e o desrespeito. Para regimes políticos que desrespeitam a democracia como um valor forte, o cultivo do pensamento na contracorrente que é o emblema decisivo da arte engajada, sempre será vista sob a suspeita da subversão. Tem medo da arte aqueles que enxergam como perigo a exposição do contraditório.

Neste ensaio propõe-se refletir a respeito da questão do engajamento artístico e intelectual tomando como mote para análise as obras de Walter Benjamin e Bertolt Doutorando em Sociologia pela Universidade de Brasília - UnB. Brasileiro, residente em Brasília. 
Brecht no período de 1930. O decênio de 30 foi o período histórico no qual eclodiram regimes totalitários na Europa cujas tensões políticas encaminharam a humanidade para os conflitos bélicos da Segunda Guerra mundial e todas as catástrofes civilizacionais que decorreram da emergência da guerra. Intelectuais e artistas em contraponto à apologia da técnica e do capitalismo, apresentam reflexões e experimentos que atuariam na contraposição à ordem das coisas. A tarefa de suprimir a alienação da sociedade burguesa, nas obras de Benjamin e Brecht, mostrou-se central no projeto intelectual dos autores durante o período de 1930. A questão do engajamento, portanto, torna-se constitutiva dos desenhos teóricos e artísticos desses dois pensadores. Benjamin e Brecht, em consonância com o pensamento dialético, propunham concepções de intelligentsia engajada nas questões essenciais de seu tempo.

Embora muitas vezes os intelectuais comprometidos nas reflexões sobre seu presente histórico tenham discordado entre si, como nos mostra a história do marxismo ocidental, suas observações sobre a modernidade contribuem com a interpretação de uma configuração histórico-sociológica da primeira metade do século XX. Nessa perspectiva, os críticos e os artistas se unem para realizar 0 reconhecimento da alienação como forma dependente e intrínseca dos problemas das sociedades capitalistas modernas. Para além da denúncia, ou melhor, da exposição das contradições sociais, esses intelectuais e artistas se dedicaram ao fortalecimento da atitude crítica como elemento para a organização contra a exploração.

Benjamin visou apresentar o problema do engajamento expondo a teoria do escritor progressista que, por sua vez, se fundamenta a partir dos experimentos estéticos do teatro épico de Brecht. A concepção de teatro reformulada pelo dramaturgo alemão se fundamenta por meio da consideração de que, para a arte, o palco deve ser visto como um ambiente da política e que a prática artística deve se orientar para o fomento do pensamento crítico da plateia. Tal afinidade entre a reflexão filosófica e o experimento teatral encontrou complexidade reflexiva no âmago do marxismo ocidental. Nesse sentido, as afinidades eletivas entre Benjamin e Brecht são decisivas, uma vez que, foi no diagnóstico da crise da cultura burguesa que ambos empregaram seus esforços intelectuais para propor contornos para o engajamento da intelectualidade. O comprometimento desses pensadores da cultura, portanto, 
conforma teoria e prática como partes constitutivas da atividade intelectual e artística. Os problemas detectados no diagnóstico da sociedade burguesa em Marx, a saber, a alienação moderna, o domínio ideológico da sociedade liberal e a progressiva exploração do proletariado, no pensamento de Benjamin e Brecht, foi retomado como impulso para o exercício da crítica. Tal perspectiva, pode ser assinalada ao examinamos os caminhos da reflexão teórica e prática dos experimentos teatrais brechtianos durante o decênio de 1930 e a recepção benjaminiana da teoria do teatro épico em sua importância para os contornos da teoria do escritor progressista.

Benjamin apresenta em seus escritos de teoria da arte a perspectiva da reabilitação dos potenciais críticos da cultura. Embora o diagnóstico sobre o avanço da técnica impacte nas dimensões aurática e ritualística da arte, Benjamin salientava que a arte na era da reprodutibilidade ainda resguardaria um potencial de crítica. Por sua vez, esse tipo de engajamento político, somente poderia ser realizado por meio da compreensão das transformações técnicas na esfera artística, tanto sob o ponto de vista filosófico para que os conceitos não sejam "apropriáveis pelo fascismo", como também, para a arte engajada, servir como mediadora entre os conteúdos críticos e a sociedade.

Para Benjamin e Brecht a politização da arte auxiliaria na publicização do pensamento crítico na sociedade capitalista e, com isso, contribuiria como contraponto ao processo de alienação do proletariado. Não se configura como um problema para a cultura o comprometimento de intelectuais e artistas na crítica à sociedade, pois, da perspectiva do marxismo defendido por esses autores, o destino da própria sociedade depende da capacidade de reação aos problemas e dilemas que se impõem no contexto histórico. Com essa atitude, o diálogo entre arte e política na esteira do marxismo de Benjamin e Brecht supera a barreira da autonomia da arte e propõe uma arte engajada nos termos de uma disputa contra a alienação do pensamento.

Como este apanhado indica, apresentamos um conjunto de diálogos intelectuais cuja preocupação central está nas potencialidades do engajamento político na arte, cujo diagnóstico de crise da sociedade burguesa é derivado dos avanços teóricos do marxismo ocidental. Mesmo com a reflexão circunscrita na primeira metade do século $X X$, as tensões sobre o papel da arte, suas contribuições e sua importância para a sociedade, mantem-se ainda hoje de forma viva. De encontro Doutorando em Sociologia pela Universidade de Brasília - UnB. Brasileiro, residente em Brasília. 
aos experimentos estéticos de uma arte politicamente engajada a interpretação do marxismo sobre a tragédia da cultura capitalista sintetizou um capítulo fundamental para a compreensão da história intelectual do século XX.

Posto isto, as considerações deste ensaio, recorrem ao conjunto de diálogos entre Benjamin e Brecht para reavivar uma proposta teórica sobre o engajamento da arte na política. Arte, politicamente situada, fundamenta um dos meios para divulgação do conhecimento crítico, isto é, o saber orientado para a reflexão, desmitificação e o desvelamento dos mecanismos de dominação moderna. Ao longo deste ensaio ficará clara a existência de dois movimentos. De um lado, a exposição da filosofia da arte nos escritos de Benjamin, por outro lado, os contornos do projeto artístico do teatro épico brechtiano. De forma interessante, os dois projetos se encontram, sendo as afinidades eletivas entre os dois pensadores interessantes para compreendermos tanto o diagnóstico de crise da sociedade burguesa, quanto a proposição do engajamento de pensadores nos problemas de seu tempo.

Antes de passarmos para o conteúdo propriamente dito do ensaio, vale destaca, o elemento epistemológico que permite a conexão entre a filosofia da arte e a produção artística. Trata-se do conceito de experiência proposto por Walter Benjamin. O conceito benjaminiano de experiência é histórico e social, pois, aproxima as experiências do tempo em sua atividade de pensamento. Experiência é compreendida num sentido amplo de conhecimentos transmitidos para uma coletividade que sintetizam os sentimentos de uma época. Nesse sentido, a exposição da arte é fundamental para o autor, uma vez que nela se encontram os registros das experiências do tempo.

Nessa lógica, as experiências apresentadas nas obras literárias são caminhos filosóficos para a investigação intelectual. Por esse vínculo Benjamin pensa a questão do engajamento. O diálogo intelectual entre Benjamin e Brecht a respeito do comprometimento intelectual com a luta de classes pode ser visto como mais um capítulo do que posteriormente ficou conhecido como marxismo ocidental. Esse capítulo da história intelectual, por sua vez, se mobiliza a partir da teoria do teatro épico brechtiano, definida como um diagnóstico dos problemas derivados do capitalismo moderno combinado com uma prática política de produção de uma arte engajada na luta de classes. Assim, a arte de Brecht se caracteriza pela crítica das 
relações humanas no capitalismo, assim, o teatro se configura como um espaço de crítica dialética.

\section{Engajamentos artísticos e intelectuais.}

No exame das obras de Walter Benjamin e Bertolt Brecht pode-se observar a emergência de um diálogo amplo e aprofundado sobre a relação entre arte e política. Como dito, o primeiro objetivo deste ensaio é realçar as afinidades eletivas entre os dois intelectuais, sobretudo, tomando como subsídio a questão da sinergia entre arte e política, teatro e crítica, presente nos diálogos intelectuais entre os dois autores no decênio de 1930. São decisivos os esforços de Brecht para a fundamentação teórica e prática do experimento artístico nomeado teatro épico.

O princípio do teatro épico é a composição de uma cena teatral em que a atuação e a trama incentivem a reflexão crítica do público. Brecht tinha como intenção realizar uma transformação das apresentações teatrais e via como antagonista de seu teatro político o desdobramento do teatro dramático burguês com raízes na poética aristotélica; Brecht identificava no autor clássico os elementos essenciais de um teatro moderno que visava efeitos puramente catárticos no público ${ }^{1}$. O antagonismo com o teatro aristotélico tinha relação com o diagnóstico de que, na fundamentação dessa forma dramática, as peças tinham o intuito simples de produção de um sentimento catártico de identificação irrefletida entre personagem e público. Para Brecht a tarefa do teatro deveria ser outra. Para ele, em contraste com o teatro dramático, o teatro épico inovaria com a exposição de um quadro de sentimentos expostos por meio do estilo épico, isto é, exercícios artísticos que promovem a dinâmica de reflexão do público durante a apresentação teatral.

\footnotetext{
1 Na Poética Aristóteles apresenta as diferentes espécies de formas poéticas, distinguindo suas características e elementos primordiais de cada uma delas num esforço primordial de formalização dos estilos. A tragédia necessita de um padrão de exposição das ações que estimulam a imitação de "fatos inspiradores de temor e pena", isto é, pressupõe na forma teatral a realização catártica. Nesse ponto, Brecht opõe a forma clássica teatral alegando que nela a identificação imediata entre cena e público impõem uma disposição para à não-reflexão. Ademais, Aristóteles contestava a comédia como uma espécie inferior de representação: "A comicidade, com efeito, é um defeito e uma feiura sem dor nem destruição; um exemplo óbvio é máscara cômica, feia e contorcida, mas sem expressão de dor." (ARISTÓTELES, 1985, 24). Para Brecht, a comédia é uma das formas teatrais para a exposição de experiências sociais, sobretudo, por tornar a experiência teatral agradável e divertida para o público, tal como, o experimento cômico auxilia no caráter didático do teatro dialético.

Doutorando em Sociologia pela Universidade de Brasília - UnB. Brasileiro, residente em Brasília. 
O teatro épico se caracteriza como um teatro materialista no qual o ser humano é apresentado como parte constituinte de um conjunto de relações sociais. O teatro épico como obra de arte se dedica à exposição das engrenagens sociais da modernidade. De acordo com os pressupostos estabelecidos por Brecht, as renovações estéticas no teatro devem prescindir uma mudança de postura dos artistas no que diz respeito a forma de apresentação. Contrário a uma concepção de arte puramente distrativa, Brecht dedicou-se à consolidação de uma apresentação que combine tanto elementos lúdicos da diversão, quanto elementos metodológicos das peças didáticas.

Ademais, como notamos até aqui, o teatro brechtiano se define como um teatro dialético, visto que, se coloca como herdeiro da tradição crítica oriunda do marxismo. A partir da herança da crítica à sociedade marxista, o teatro épico reclama, ainda, a possibilidade de investigar, analisar e exercitar as relações sociais de forma que o público possa interpretar os fatos do mundo no qual está inserido. Ele não pressupõe e objetiva uma identificação imediata da plateia com as personagens e com o público, ao contrário, ele se caracteriza pela apresentação de situações no qual o conjunto de relações sociais está representado e o público pode aprender com o decorrer do processo.

Em inúmeros textos estão formulados os princípios do teatro épico. Brecht meticulosamente articulava as condições para a execução do teatro épico com a encenação, a montagem da cena, a música e a preparação da plateia. Na peça teatral Um homem é um homem, escrita entre 1924 e 1925, parece-nos um exemplo marcante para a forma com que Brecht executa o teatro épico como crítica reflexiva da cultura. Neste experimento teatral o dramaturgo dedica-se à realização da metamorfose de um homem no palco: de um pacato estivador passa a ser um soldado sombrio e disciplinado. O herói proletário, Galy Gay, ao se envolver numa confusão com soldados britânicos acaba tendo que assumir uma outra identidade, a de Jeraiah Jip. A mudança de identidade acompanha uma mudança no humor da personagem, sendo, o câmbio dos nomes o sinal para a existência de uma segunda vida social. Se, enquanto estivador, a tranquilidade nas relações sociais se firmava como imperativo a personagem, no papel de um soldado tem sua metamorfose completa num ato de corrupção do caráter.

Doutorando em Sociologia pela Universidade de Brasília - UnB. Brasileiro, residente em Brasília. 
Brecht utiliza-se da técnica da interrupção cênica para dialogar com a plateia. Na Peça Um homem é um homem o recurso é utilizado para chamar atenção do público para a facilidade de substituição e transformação de um indivíduo, afinal, um homem é um homem. A prontidão com a qual o indivíduo abandona seus valores mais subjetivos para atuar numa corporação que, para ele até pouco tempo nada significava, é a proposição reflexiva assinalada por Brecht. Galy Gay, o homem que não sabia dizer não, metamorfoseado em um soldado britânico, passa a reconhecer na guerra apenas o que lhe é agradável. No interlúdio da peça, sinaliza Brecht:

O senhor Bertolt Brecht afirma: um homem é um homem/ $E$ isso qualquer um pode afirmar/ Porém o senhor Bertolt Brecht consegue também provar/ que qualquer um pode fazer com um homem o que desejar/ Esta noite, aqui, como se fosse um automóvel, um homem será desmontado/ E depois, sem que dele nada se perca, será outra vez remontado (BRECHT, 1990, 181).

Ao trazer a público a metamorfose de um homem, Brecht põe em prática os pressupostos de exposição de uma crítica à sociedade no teatro épico. Fortificado por recursos cênicos e técnicos, o teatro dialético, se afirma como um experimento artístico de contraposição à alienação, na medida em que visa, como objetivo, apontar as contradições das relações sociais desenvolvidas no âmago do capitalismo. A reflexão proposta pela peça leva ao público inquietações referentes à manipulação e ao problema da dominação ideológica. A personagem que se metamorfoseia no palco apresenta, de forma didática, o problema da dominação social.

Em poucas palavras, os arranjos teóricos e práticos do teatro épico podem ser arrolados da seguinte maneira. Embora em cada peça os princípios sejam flexíveis e adaptados a diferentes tramas e personagens, Brecht manteve como elemento chave do seu teatro a questão da crítica dialética da sociedade. A exposição das engrenagens sociais, por essa perspectiva, é o que melhor sintetiza o engajamento do projeto artístico brechtiano. Em relação ao contexto histórico, o teatro dialético emerge no cenário alemão entre nas décadas de 1920 e 1930 contrapondo-se de forma ferrenha à apologia aos conflitos bélicos e ao avanço do totalitarismo. Nesse sentido, o engajamento da arte, naquele contexto, em alguma medida, se mostra condicionado a ser reativo aos problemas daquela sociedade. Por outro lado, ele também apresenta uma faceta propositiva ao defender uma postura de educação crítica. 
Os empreendimentos artísticos de Brecht ganharam ressonância tanto na arte, quanto na crítica especializada. Os escritos de Benjamin sobre Brecht, para além da apresentação de uma amizade intelectual, fornecem-nos o retrato da recepção dos empreendimentos artísticos de Brecht na década de 1930. As afinidades eletivas entre os dois intelectuais podem ser vistas num ponto central de encontro entre eles: a busca pelo fortalecimento da crítica e o reconhecimento da necessidade do engajamento intelectual. Se Brecht colocou em prática um projeto artístico dedicado ao comprometimento com os problemas de seu tempo, por sua vez, Benjamin também o fez, situando a crítica como ferramenta de transformação da sociedade.

Os escritos de Benjamin sobre o teatro épico brechtiano destacam a importância dos empreendimentos artísticos críticos para a mediação entre a teoria e prática revolucionária. Os acentos decisivos do marxismo nas peças de teatro de Brecht são assinalados sob o signo de um instrumento de contraponto à alienação da sociedade. Nesse sentido, para Benjamin, as transformações teóricas no teatro acompanham o mesmo movimento social. As mudanças que alteram o pano de fundo do mundo moderno incitam as vanguardas artísticas para a realização de transformações, no caso do teatro, o câmbio se dá na abolição das barreiras entre palco e público.

No teatro épico a trama toma o palco de forma convidativa. Benjamin (2017) via na formulação do teatro dialético a liquidação da separação rígida entre palco e público. Nessa nova forma de apresentação, o público sente-se cada vez mais convocado à participação. Palco e vida partilham do mesmo substrato social e, por esse motivo, a politização da trama perpassa a identificação plena entre indivíduo e situação. No entanto, o teatro épico de Brecht não se define pela simples reprodução de situações sociais. O que Benjamin ressalta é a importância enfática de noções como processo e experiência. Os dois conceitos auxiliam na condução e na captação da mensagem política do teatro dialético. Todos os elementos cênicos que vimos antes como a interrupção, a exposição da crítica e a predominância do diálogo entre palco e público contribuem para uma experiência objetiva de interpretação crítica da situação exposta em sua processualidade: "Ou seja, o teatro épico não reproduz situações; antes, as revela. A revelação das situações acontece por meio da interrupção dos processos." (BENJAMIN, 2017, 14). 
No processo de exposição da experiência artística o teatro épico ocupa o público com reflexões sobre as relações sociais, ausentando-as de toda espécie de proposição panfletária. $O$ teatro épico, como um teatro politizado, reinforma 0 interesse do público situando-o no interior das situações sociais impostas. Não aposta na partidarização imediata e essencialmente empática com as injustiças sociais, pretende ir além, ou seja, propor uma reflexão sobre as raízes das injustiças sociais. A despeito disso, Benjamin (2017) no comentário sobre a peça de Brecht intitulada $A$ mãe, destaca a forma com que o dramaturgo insere a questão da exploração no capitalismo num amplo complexo de relações familiares, políticas e econômicas.

No ensaio Um drama familiar no teatro épico, Benjamin contrasta as teses defendidas pela direita política a respeito da radicalidade do comunismo invertendo o argumento. Não seria o comunismo radical, mas sim, o capitalismo o modo de produção mais radicalizado, uma vez que:

Brecht afirmou que o comunismo é o meio-termo (das Mittlere). 'O comunismo não é radial. O capitalismo é radical.' Reconhecemos o quanto ele é radical por seu comportamento em relação à família, bem como em relação a qualquer outro ponto. Ele se exacerba mesmo quando qualquer intensificação da vida em família acirra o sofrimento de condições humanas indignas (BENJAMIN, 2017, 39).

Na peça épica $A$ mãe de 1931, Brecht tematiza a questão da guerra e da exploração capitalista por meio da personagem Pelagea Wlassova: "viúva de operário e mãe de um operário". De forma interessante, a personagem principal de $A$ mãe também realiza uma metamorfose no palco, embora, dessa vez, em contraste com a peça Um homem é um homem, a transformação sublinhe uma postura inicial de oposição à postura revolucionária do movimento operário, para no final, a partir de uma reflexão crítica, se alinhar a luta contra a exploração. De acordo com Benjamin (2017) o texto teatral é elucidativo ao iluminar a questão do esclarecimento político, uma vez que, viu na experiência da personagem de Pelagea Wlassova os resultados das diversas explorações sociais modernas.

Benjamin (2017) viu na personagem de $A$ mãe o sinal da dupla exploração social, de um lado, a exploração da família, por outro lado, a exploração na produção capitalista. Enquanto artefato artístico esse ensaio evidencia a prática da teoria do teatro épico, posto em prática na experiência de uma personagem que compartilha a experiência da injustiça com o público. 
Sob as condições atuais, a família é uma organização para a exploração da mulher como mãe. Pelagea Wlassova, 'viúva de trabalhar e mãe de trabalhador', é duplamente explorada, representa os explorados em seu mais profundo aviltamento. Se as mães forem revolucionárias, nada restará a revolucionar. O objeto de Brecht é uma experiência sociológica sobre a transformação revolucionária da mãe (BENJAMIN, 2017, 39).

A experiência sociológica, a qual se referiu Benjamin está no centro da arte engajada de Brecht. As situações sociais, colocadas sob o signo da problematização, conduzem a plateia para uma atitude crítica diante das relações sociais nas quais eles mesmos se inserem. No cenário histórico de desenvolvimento artístico da primeira metade do século $X X$ a prática crítica revolucionária se canalizou na atuação dos partidos de esquerda. Não é desconhecida a predileção de Brecht pela via da organização política partidária. Em suas peças teatrais, as próprias personagens encontram um caminho de organização da política. Benjamin (2017) relembra essa característica ao sugerir uma relação orgânica entre as personagens proletárias e a atuação político partidária.

Vale para o teatro de Brecht e a crítica de Benjamin a posição de contraponto, naquele contexto histórico, postura antagonista à ascensão dos regimes totalitários da década de 1930. A eclosão do fascismo não foi um exemplo espontâneo que emergiu em 1933 na Alemanha. O temor da instrumentalização da atmosfera de descontentamento social e anseio por mudanças pelo status quo habitou o imaginário da intelligentsia de esquerda marxista. Em sua tese sobre a estética da guerra, Benjamin (1987) observou como a estetização da vida política permitiu aos regimes fascistas se apropriarem dos anseios populares para fins de controle totalitário da sociedade. O aumento quantitativo do proletariado nas sociedades modernas fez com que essa classe passasse a ser disputada tanto pela esquerda, quanto pela direita. Embora os regimes fascistas mantivessem um discurso sobre a transformação do regime de produção em benefício do proletariado, como funcionários do status quo, eles somente manipulariam o desejo por igualdade, oferecendo em contrapartida apenas mais repressão:

O fascismo tenta organizar as massas proletárias recém-surgidas sem alterar as relações de produção e propriedade que tais massas tendem a abolir. Ele vê sua salvação no fato de permitir às massas a expressão de sua natureza, mas certamente não a dos seus direitos (BENJAMIN, 1987, 194).

O fascismo consegue o apoio das massas por meio da falácia da transformação da sociedade. A experiência histórica mostra que o compromisso do totalitarismo se 
restringe ao controle e a destruição de seus opositores, principalmente, escudados por uma máscara ornamentada por emblemas moralizadores e clichês reacionários. Nesse cenário de inquietude política e social, para parte da intelectualidade na qual estavam inseridos Brecht e Benjamin, era tarefa inadiável a questão do engajamento na luta política. Para Benjamin a politização da arte se mostrava como uma via de difusão do esclarecimento, como veremos mais adiante. Porém, para Brecht, o engajamento da arte propiciaria os elementos de percepção de classe que contribuiriam para uma luta política partidária.

A arte engajada de Brecht permite a transposição da esfera da individualidade da vida social para uma compreensão mais ampla do conjunto das relações sociais na qual o sujeito está imerso. Do ponto de vista da experiência estética, ela sugere os caminhos necessários para a adoção de uma visão de mundo coletiva. A exploração que afeta um indivíduo é a mesma que lesiona a totalidade do social. Entendendo o exercício teatral como um processo de reflexão e inserção de uma forma de "consciência de classe", pode-se entender o papel primordial que Brecht concedeu a luta partidária. No famoso poema Elogio do partido, diz Brecht:

O indivíduo tem dois olhos

O Partido tem mil olhos.

O Partido vê sete Estados

O indivíduo vê uma cidade.

O indivíduo tem sua hora

Mas o partido tem muitas horas.

O indivíduo pode ser liquidado

Mas o partido não pode ser liquidado.

Pois ele é a vanguarda das massas

E conduz a sua luta

Com os métodos dos Clássicos, forjados a partir

Do conhecimento da realidade (BRECHT, 2012, 115)

A arte engajada de Brecht, ao promover uma postura crítica do público, coincide a formação de um movimento reflexivo com uma noção de totalidade. A consciência de classe que deriva do experimento teatral brechtiano enfatiza a relevância de uma 
atuação coletiva como forma de oposição a explorações capitalistas. Do ponto de vista teórico, essa afinidade eletiva já assinala o compromisso do autor com o marxismo, sendo seu teatro engajado produto de crítica à alienação da modernidade. Nesse sentido, Brecht (1967) supera a trama defendida pela intelectualidade "descompromissada" com seu momento histórico ao desenvolver um experimento artístico que coaduna a perspectiva da estética e de uma sociologia crítica. Nas duas dimensões do processo o que está em jogo é uma inovação no que diz respeito a práxis. Possibilidade de conexão que Benjamin observou ser a característica fundante das tramas brechtianas e sintetiza na leitura do texto $A$ mãe, a saber: "A mãe tornouse a prática encarnada" (BENJAMIN, 2017, 41).

Vimos, portanto, o desenho da questão da arte e da crítica engajada na obra de Brecht e Benjamin. A ideia da conexão entre a reflexão artística e a política encontrou um caminho fértil na reflexão sobre o teatro épico. Do ponto de vista de uma leitura da crítica, a obra de Benjamin do período retoma o papel central arte na disseminação de uma postura crítica e como forma de mediação entre teoria e prática. A seguir analisaremos a teoria do escritor progressista de Benjamin e seus desdobramentos para a politização da arte.

\section{A teoria do escritor progressista, ou, a leitura benjaminiana do teatro épico de Brecht}

A preocupação com a arte, mais especificamente, sobre o papel dela como mediadora para o esclarecimento, esteve no centro das preocupações de Benjamin na década de 1930. Os ensaios do período são documentos que evidenciam a primazia da reflexão sobre os caminhos da arte numa sociedade em que a técnica e a racionalidade se apresentavam como bases para a reflexão da intelectualidade engajada. Em contraponto a outros intelectuais do período, Benjamin vislumbrava na arte os potenciais de um engajamento político. É nesse sentido que ele discute o mérito do teatro épico de Brecht. Com o dramaturgo, Benjamin cultivou uma amizade intelectual e uma afinidade no que diz respeito ao papel dos intelectuais no contexto de exploração moderno (WIZISLA, 2007). O retrato mais fidedigno das afinidades eletivas entre os dois autores é o ensaio $O$ autor como produtor, escrito por Benjamin em 1934. 
Em $O$ autor como produtor Benjamin transpõe suas reflexões sobre a filosofia da arte para expor o entrelaçamento da teoria e da prática do escritor progressista. $O$ texto é central para pensarmos a aproximação do autor com o marxismo, sobretudo, aquele que deriva da herança de História e consciência de Classe de 1923. No campo de estudos do pensamento benjaminiano é comum o destaque para o texto de Lukács como primordial para a inclinação de Benjamin em relação as teses do marxismo em sua expressão científica e política. Lembram também que a "virada marxista" se deu a partir dos contatos mais aproximados com Asja Lacis. A dramaturga letã ainda nos anos 20 inseriu Benjamin nos debates sobre a importância da práxis política na tempestuosa Europa nos Pós-Primeira Grande Guerra. Em outra perspectiva apontam em Brecht os primeiros estímulos para uma reflexão "mais marxista". Do ponto de vista da análise dos ensaios produzidos no período essas hipóteses também fazem sentido, uma vez que, com a análise da experiência do teatro dialético, Benjamin escreveu ensaios no qual o marxismo irrompe como uma força de condução para a práxis.

Lukács, Asja Lacis² e Brecht, evidentemente, são três fontes fundamentais de diálogo intelectual na obra de Benjamin. As três hipóteses são razoáveis para uma interpretação profunda de sua obra, embora, também pareça ser coerente evitar favorecer o imperativo desse conjunto de diálogos a noção simples de "influência". O marxismo insere-se nos textos de Benjamin de forma sui generis, conforme sugerem muitos intérpretes da obra do autor como Konder (2003), Santos (2018), entre tantos outros. Se não podemos apontar uma única ponte de diálogo do autor com essa tradição de pensamentos, assim como, não devemos menosprezar a pesquisa sobre os escritos de Marx para a confecção do Trabalho das Passagens [Das PassagenWerk] é aceitável ver na leitura marxista de Benjamin o sinal da reabilitação teórica a partir das experiências da modernização no século $X X^{3}$. A polifonia do pensamento

\footnotetext{
2 Em uma carta enviada por Benjamin à Asja Lacis, datada de fevereiro de 1935, podemos compreender com mais detalhes a parceria intelectual entre o filósofo e a dramaturga. Na ocasião, Benjamin prepara um ensaio que, ao que tudo indica, o Sobre a posição social do escritor francês. A correspondência sugere que Asja Lacis estaria disposta a receber o texto e acrescentá-lo em uma publicação especializada em Moscou. Com o prosseguimento das investigações sobre a obra de Benjamin, parece-nos evidente a importância da inclusão dos diálogos com Asja Lacis na agenda de pesquisa atual. A referida carta de 1935 oferece um apontamento sobre um estreito diálogo intelectual e engajado politicamente.

${ }^{3}$ Dos diálogos com Lukács, Asja Lacis e Brecht, apenas com o dramaturgo possui vasta documentação e pesquisa. Em relação a Asja Lacis a situação é ainda mais problemática, uma vez que, dos inúmeros Doutorando em Sociologia pela Universidade de Brasília - UnB. Brasileiro, residente em Brasília.
} 
benjaminiano levou em considerações toda espécie de pensamento que se colocava na contracorrente do status quo que, de fato, incluiu diversas propostas de escritores, tal como Brecht, Louis Aragon, Franz Kafka, Edgar Allan Poe, Charles Baudelaire, bem como de revolucionários como Blanqui.

A questão do engajamento teórico de Benjamin também pode ser acompanhada internamente, isto é, por meio da análise da sua produção intelectual. Foi no continuamente retrabalhado ensaio $A$ obra de arte na era de sua reprodutibilidade técnica (1934) [Das Kunstwerk im Zeitalter seiner technischen Reproduzierbarkeit] que Benjamin apresentou algumas proposições a respeito do engajamento da arte. Nas conhecidas reflexões iniciais, o autor busca formular uma teoria filosófica da arte que não fosse manipulável por uma visão de mundo fascista. Para refletir sobre a cultura era necessária a produção de novos conceitos de teoria da arte e, nesse sentido, a reabilitação das próprias noções de crise e crítica da sociedade moderna:

Os conceitos seguintes, novos na teoria da arte, distinguem-se dos outros pela circunstância de não serem de modo algum apropriáveis pelo fascismo. Em compensação, podem ser utilizados para a formulação de exigências revolucionárias na política artística (BENJAMIN, 1987, 166).

A tensão entre estetização da política e politização da arte sinaliza a preocupação do autor, sobretudo após o ano de 1933, sobre o problema da apropriação da experiência artísticas para fins de controle e dominação dos regimes totalitários como, por exemplo, a instrumentalização do cinema como ferramenta de propaganda. Nesse sentido, em seu ensaio sobre $A$ obra de arte, Benjamin advoga em favor do que aduz ser a politização da arte, ou seja, a capacidade de conversão dos novos elementos técnicos de difusão da arte em uma perspectiva de fomento da

volumes de correspondências analisadas durante a pesquisa, foram encontradas poucas cartas trocadas entre os dois, sendo, a maioria das menções sendo constituídas apenas de referências indiretas em relação à dramaturga. Uma das escassas fontes testemunhais da relação entre Asja Lacis e Benjamin é a autobiografia da diretora intitulada Revolutionär im Beruf, no qual existem poucas citações sobre Benjamin. No que diz respeito a leitura de Benjamin dos escritos do próprio Marx, o Trabalho das Passagens nos concede um itinerário de leitura e reflexão do autor. São citadas as seguintes obras de Marx: O capital, sobretudo o capitulo sobre o processo de troca e o fetichismo da mercadoria; o texto Sobre a questão judaica, a Crítica ao Programa de Gotha. Defendemos como hipótese a importância de História e consciência de classe de Lukács para a leitura do diagnóstico da crise da sociedade burguesa na obra de Benjamin. Desse ponto de vista, conceitos como reificação e totalidade são traduzidos para a filosofia benjaminiana como "sintomas" da crise da sociedade capitalista.

Doutorando em Sociologia pela Universidade de Brasília - UnB. Brasileiro, residente em Brasília. 
crítica à sociedade burguesa ${ }^{4}$. Em poucas palavras: Benjamin indica que somente com a politização da arte, naquele contexto, o comunismo poderia contrapor-se à investida do fascismo. Brecht notou esse potencial ainda na década de 1920 quando os regimes totalitários ascendiam nas sociedades europeias. Benjamin via no surgimento das vanguardas artísticas a possibilidade de crítica à técnica e ao progressismo, percepção compartilhada por seu amigo dramaturgo, especialmente, no que diz respeito as novas técnicas de montagem e experimentação artísticas.

A teoria do escritor progressista emerge nesse cenário de diálogos e do diagnóstico da crise social da sociedade burguesa, em certo sentido, a dimensão trágica da alienação e da exploração nas sociedades modernas. Isto posto, é decisivo reconhecer o ensaio $O$ autor como produtor como um ponto chave referente às leituras e releituras a respeito do teatro épico brechtiano, mas, sobretudo, um ensaio colocado na herança do marxismo ocidental. Já vimos que, no final da década de 1920, Brecht investe seus esforços intelectuais para promover uma forma artística que, grosso modo, busca a não-alienação do público por meio do fomento da reflexão crítica nas peças. Esse laboratório artístico e intelectual foi fundamental para Benjamin, visto que, pôde observar na gênese do teatro épico a formação de uma crítica marxista que, à sua forma, se alicerça na exposição das contradições da sociedade capitalista.

A questão que serve como prelúdio para o ensaio de Benjamin é relativa ao papel da autonomia da arte e do artista. No que diz respeito a sua situação como ser social enredado na história, o artista de forma inescapável está associado a um estrato da sociedade. Na modernidade, a questão da condição social é mascarada, desse modo, o artista não se veria inserido no complexo de relações sociais da sua sociedade. Para Benjamin, o tipo mais progressista de autor compreenderia a sua

\footnotetext{
${ }^{4}$ No ensaio citado, Benjamin reconhece as diversas dimensões do problema, sendo, as soluções destacadas anteriormente apenas uma camada da problemática da reprodutibilidade da arte. Nesse sentido, vale, destacar, que o autor observa o movimento da arte num sentido dialético, isto é, na mesma medida em que observa os avanços para a politização da arte através de sua difusão para o público, também, via na questão do decaimento da aura o contraponto da maior "disponibilidade" da arte. As teses desenvolvidas no ensaio sobre a reprodução da arte em muito adiantam a perspectiva do engajamento da arte desenvolvidas no ensaio O Autor como produtor que também é de 1934. No entanto, há uma divergência contida, especialmente, ao serem destacados elementos de críticas tanto para os "produtores" de arte, mas também de seus "consumidores" num movimento próximo as críticas culturais desenvolvidas por Adorno a partir de 1940 com a ideia de indústria cultural.
} 
possibilidade de se aliar de forma alternativa, ligando seu trabalho a um interesse político:

\begin{abstract}
Vocês acreditam que a situação social no presente obriga-o a decidir a serviço de quem ele quer exercer sua atividade. $O$ autor burguês de literatura de entretenimento não reconhece essa alternativa. Vocês lhe demonstram que ele está, sem admitir, a serviço de determinados interesses de classe. Um tipo mais progressista de autor reconhece a alternativa. Conforme se coloca do lado do proletariado, sua decisão se baseia na luta de classes. E assim cessa sua autonomia. Ele direciona sua atividade pelo que é útil para o proletariado na luta de classes. Costumamos dizer que ele segue uma tendência (BENJAMIN, 2017, 85, grifos nossos).
\end{abstract}

A tendência do encontro entre política e literatura, de acordo com Benjamin, resguarda ao escritor consciente de sua situação social a capacidade de admitir a conexão de sua obra com a luta de classes. Se reconhece que com esse alinhamento da arte com a política há uma suspensão da questão da autonomia, no entanto, como pano de fundo a esse argumento, há o diagnóstico de que a defendida "autonomização" da arte literária como uma esfera apartada do social, apenas é admitida pelos escritores endireitados com a ordem social vigente. A vinculação da produção literária para a utilidade do proletariado parte do diagnóstico da centralidade da cultura para a estrutura da modernidade.

Benjamin (2017) defende esse ponto ao alegar que a produção cultural deve estar integrada ao conjunto de "relações sociais vivas" (BENJAMIN, 2017, 86). Do mesmo modo que o texto brechtiano visava revelar as relações sociais na qual o indivíduo estava inserido, Benjamin defende algo análogo como representativo da postura progressista do escritor. Para Benjamin importa o estatuto conferido a descrição e a apresentação das relações de produção que são representativas de um tempo histórico.

Partindo do pressuposto do entrelaçamento da arte e política, Benjamin defende que o escritor progressista realiza a combinação entre a dimensão artística e política. Esse intelectual que está entre o crítico e o artista tem como compromisso promover uma crítica das relações sociais em sua totalidade. Para Benjamin, Brecht apresenta essa atitude intelectual em sua obra, pois reúne a crítica das relações sociais com as necessidades de apresentação da obra de arte. As experiências representadas nos textos teatrais carregam consigo o potencial de revelação das 
contradições da sociedade capitalista e, por essa perspectiva, contribuem no combate ao fetichismo diagnosticado como sintoma do modo de produção atual no marxismo.

Com Brecht, os potenciais da arte como meio de transformação foram potencializados na leitura crítica de Benjamin. O ensaio O autor como produtor (1934), resultado de uma palestra proferida no Instituto para o Estudo do Fascismo, de Paris, é representativo de uma leitura crítica do experimento do teatro épico. Benjamin advoga que o escritor, munido de sua liberdade artística, somente pode ser tipificado como "progressista", na medida em que situa sua produção na luta de classes. A elaboração de um tipo ideal do escritor progressista - para lembrarmos o instrumento heurístico weberiano - responde à inquietação sobre o papel destes intelectuais na luta política e, mais do que isso, pensa em quais seriam suas contribuições para uma prática emancipadora.

Essa explanação benjaminiana situa a intelligentsia no processo produtivo, porém, na perspectiva da esquerda alemã, o movimento somente se conclui na medida em que esse intelectual se situe com o proletariado [mit dem Proletariat]. A concepção de artista comprometido com a luta de classes é exemplificada, por Benjamin, através da própria produção de Brecht. O teatro épico brechtiano mostravase crucial para Benjamin, visto que, mobilizava tanto autores quanto o público para, primeiramente a reflexão mediada pelo conhecimento, em segundo lugar, a modificação da sociedade. O conceito que Benjamin retoma é a mudança de função [Umfunktionierung] apresentado por Brecht para sugerir a transformação da sociedade num sentido progressista.

Portanto, para os contornos da teoria do escritor progressista benjaminiana foi na obra de Brecht que a correspondência entre arte e política revigorou a intelectualidade alemã. O conceito de intelectual engajado, isto é, aliado a luta de classes, expressa a consonância entre o crítico e o dramaturgo. De modo interessante, o conceito de intelectual mobilizado nessas reflexões passa a situar o escritor como membro de uma classe intelectual que passa processualmente a se comprometer com a questão produtiva e a luta de classes, de acordo com Benjamin (2017). A intelectualidade progressista, por essa perspectiva: "E assim retornamos à tese apresentada no início: o lugar do intelectual na luta de classes só pode ser 
definido - ou melhor, escolhido - por sua posição no processo produtivo." (BENJAMIN, 2017, 91).

As referências acima a postura do intelectual engajado pode ser propriamente compreendida na medida em que o autor se dedica a uma atividade que visa a transformação dos meios que, na tradição de Benjamin e Brecht, sintetizadas no conceito de aparelho. O aparelho é o veículo de transmissão da ideia, por exemplo, no caso da arte de Brecht, o meio é o teatral. Benjamin defende que não basta a tomada dos aparelhos para a realização de uma ação revolucionária. Em sua característica tentacular, a industrialização da cultura incorpora a intelectualidade aos meios de produção, tal como, propõe a esses mesmos indivíduos uma atuação como "funcionários" da ideologia dominante. Para Benjamin (2017), a cooptação desses intelectuais à produção capitalista parte do pressuposto da utilização de sua "mercadoria" como instrumento de distração das massas. A inserção no aparelho que não pressupõe a metamorfose interna dos meios levaria a intelectualidade a um processo de descomprometimento com os fins de crítica e, consequentemente, um apoio a atual conjuntura.

Estamos diante do fato (para o qual a última década na Alemanha proporcionou muitas comprovações) de que o aparelho burguês de produção e publicação assimila impressionantes quantidades de temas revolucionários e até consegue propagá-los sem questionar seriamente a própria existência ou a existência da classe que o detém. [...] E afirmo novamente que uma parte considerável da assim chamada literatura de esquerda não tinha outra função social que não a de sacar continuamente novos efeitos da situação política a fim de distrair o público (BENJAMIN, 2017, 92).

Benjamin (2017) observa que a simples inclusão da temática revolucionária nos veículos de cultura não proporciona, evidentemente, uma ação revolucionária. Embora, na aparência, a classe produtora possa ter a impressão de favorecimento de sua causa, a ausência de uma reflexão sobre o próprio aparelho atua como uma ferramenta de distração e acomodação das pretensões de transformação. Esse elemento que buscou ser evitado nas formulações do teatro épico, visa a eliminação da aparência de pura distração do teatro clássico na aposta de que, com essa postura, o público se sinta inserido no conjunto de relações sociais ali apresentado. Brecht realiza esse movimento por meio de um ataque direto as formas tradicionais de representação teatral. Nessa postura de inconformidade com o aparelho, Benjamin via o exemplo máximo da postura de um artista com preocupações autênticas com a 
transformação. Nas peças do teatro épico as investidas da arte ilusionista são contrabalanceadas pela transformação do autor como produtor, isto é, a partir do procedimento de dissolução das noções de produção intelectual típicas da ordem burguesa. A intelectualidade que questiona o aparelho realiza um ataque enfático as noções da arte estabelecida ao propor uma mediação formativa que transforma os espectadores em colaboradores.

\begin{abstract}
A melhor tendência é errada se não mostra a atitude com a qual temos de segui-la. E o escritor só pode apresentar essa atitude quando faz alguma coisa: ou seja, quando escreve. A tendência é a condição necessária, nunca suficiente, de uma função organizativa das obras. Essa exige ainda 0 comportamento diretivo, instrutivo, daquele que escreve. Um autor que não ensina nada aos que escrevem não ensina nada a ninguém. Dessa maneira, o caráter de modelo da produção é decisivo: primeiro, deve-se orientar os outros produtores na produção e, em segundo lugar, disponibilizar-Ihes um aparelho melhorado. E esse aparelho é tanto melhor quanto mais consumidores levar de volta à produção; ou seja, quanto mais for capaz de transformar leitores ou espectadores em colaboradores. Trata-se do teatro épico de Brecht (BENJAMIN, 2017, 95, grifos nossos).
\end{abstract}

Os avanços técnicos no campo teatral desenvolvidos por Brecht desencadeiam um tipo específico de progresso político, sobretudo, pela transformação do espectador em pensador. Brecht (1967) ao escrever sobre o efeito do teatro épico no público, destaca que o teatro, a literatura e as artes em geral, tem a capacidade de formar uma mentalidade crítica qualificada para responder aos problemas postos em nosso tempo histórico. Nesse sentido, o teatro épico se afirmava como a arte do seu tempo, uma vez que, conduzia as questões contemporâneas da sociedade de forma mediada e pedagógica. No exercício de reflexão situacional, a representação do teatro épico, levou as últimas consequências a ideia de um teatro de formação humana, de acordo com Brecht: "Só um novo objetivo pode conduzir a uma nova arte. O novo objetivo é a pedagogia." (BRECHT, 1967, 48).

Do ponto de vista da crítica, Brecht realizou uma melhoria no aparelho, especialmente, revolucionando os elementos técnicos no qual a arte teatral encontrava-se imobilizada. A revolução no aparelho, defendida por Benjamin, está imbricada com a ideia brechtiana de defesa da arte como mediadora de conhecimentos humanos. A representação atinge um ponto inteligível, isto é, didático, no qual a condução da mensagem fomente uma postura crítica da plateia, sem que com isso seja necessário grandes excursões e empreendimentos complexos. No cenário em que as vanguardas apostavam no extremo subjetivismo artístico, Brecht 
contrapôs o caráter inacessível da arte com um teatro pedagógico que valorizava os potenciais críticos e criativos dos produtores como colaboradores.

No palco da modernidade são as experiências do que Benjamin chamou de "heróis surrados" que despertam o potencial crítico do teatro épico. São esses heróis que sugestionam a combinação entre a necessidade da ação política e os conteúdos essenciais para a organização da luta. As experiências dos heróis surrados servem como mediação entre a situação individual e a situação coletiva. Do ponto de vista materialista, o que está em pano de fundo para essa conexão é um conceito enfático de totalidade. Com o conceito de totalidade as diferentes dimensões da vida em sociedade passam a compor uma constelação social, ou, para ficarmos com a definição marxista, compõe o conhecimento de uma realidade concreta.

\begin{abstract}
Ele opõe a obra de arte total ao laboratório dramático. Ele retrocede, de uma nova maneira, à antiga grande chance do teatro - à exposição do que é presente. $O$ ser humano está no centro de suas experiências. O homem de hoje; ou seja, um homem reduzido, resfriado num ambiente frio. Mas como esse é o único que está à disposição, temos interesse em conhece-los. Ele passará por provas, avaliações. O resultado é o seguinte: o acontecimento não pode ser alterado em seus pontos altos, não por meio da virtude e decisão, mas simplesmente em seu transcurso rigidamente habitual, por meio da razão e do exercício (BENJAMIN, 2017, 97).
\end{abstract}

Assim sendo, a teoria do escritor progressista benjaminiana pressupõe a relação revolucionária dos intelectuais, artistas e escritores, com os aparelhos de produção, ou seja, uma postura de transformação das próprias estruturas na qual essa intelligentsia se encontra inserida. A integração da obra com o conjunto de relações sociais vivas presume um comprometimento da divulgação do conhecimento de forma didática. A arte que se pretende engajada apresenta em sua estrutura os elementos para a formação de um público crítico, como por exemplo, dissolvendo as barreiras entre palco e público, apresentando as conexões entre experiência individual e colaboração coletiva ou retirando os efeitos "ilusionistas" do teatro tradicional.

O processo de politização da arte depende de uma postura de inquietação diante das injustiças sociais para efetuar o que Benjamin denominou como a transformação do espectador em colaborador. Assim, o escritor progressista, ou seja, alinhado a luta revolucionária, condiciona os elementos pedagógicos de sua arte com uma noção enfática de totalidade. A ideia de totalidade é essencial para essa discussão, uma vez que, é com ela que o método materialista opera as mediações 
necessárias entre o esclarecimento teórico e a prática política. No teatro brechtiano são os conhecimentos, a reflexão transmitida e o incentivo para a organização política. Por fim, ideia de escritor progressista, como vimos, já sugere uma energética oposição as investidas mistificantes e alienantes do totalitarismo.

Resumidamente, tanto a obra de Brecht quanto a obra de Benjamin, podem ser lidas como empreendimento artístico e intelectual dedicado à transformação dos meios de produção do pensamento. As teses sobre o engajamento da arte, a teoria do escritor progressista, o desenvolvimento de um teatro político, a crítica as vanguardas vazias, a revolução dos aparelhos de reprodução, a proposição de um conceito de intelectual engajado, em todos sentidos expostos, somente fazem sentido, quando lidos num cenário de uma sociedade em crise.

Nesse sentido, crise e crítica são conceitos tão dialéticos quanto civilização e barbárie. Nas trincheiras do conhecimento e da política Brecht e Benjamin uniram forças para a formação de um conceito de intelectual totalmente comprometido com o debate público de sua sociedade. O programa da revista Crise e crítica, pensada pelos dois pensadores, explicita as intenções desse projeto no qual a questão do engajamento é central para a formação de um público de leitor crítico.

\section{Crise e crítica: notas sobre um projeto de periódico engajado}

As afinidades eletivas entre Brecht e Benjamin, como vimos, convergem no entrelaçamento da reflexão marxista sobre a indissociabilidade entre teoria e prática. A postura crítica fomentada tanto pelo teatro épico quanto pela teoria do escritor progressista, podem ser lidas como proposições de resposta às crises impostas pela moderna sociedade capitalista. De tal modo, pode-se ver o sinal da correspondência intelectual entre o dramaturgo e o filósofo no projeto da revista Crise e Crítica [Krisis und Kritik]. A constituição de ideias a respeito do papel da arte na luta política teve convergência numa perspectiva conjunta entre Benjamin e Brecht por parte dos esforços para a criação da revista de pensamento crítico Krisis und Kritik. Se, durante 1930, os dois intelectuais se notabilizaram através dos seus trabalhos como críticos de literatura e filósofo e como dramaturgo, respectivamente, foi na tentativa de sistematização de um projeto intelectual colaborativo que podemos encontrar mais elementos para examinarmos o diálogo entre arte e política. 
O memorando do projeto indica as seguintes diretrizes teóricas do periódico, a saber: 1) ser uma revista dedicada a resumir e difundir pensamentos críticos e teóricos; 2) ter seu caráter político ancorado na consciência crítica da sociedade atual do ponto de vista da luta de classes; 3) ser um órgão da consciência burguesa, no entanto, ciente da justiça e da demanda do proletariado (BENJAMIN, 1985). No vasto conjunto de reflexões, a proposta da revista Crise e Crítica tinha como objetivo fundamental o fomento e a disseminação do pensamento crítico na sociedade. Nesse sentido, o projeto, em parte, se apresenta como representativo das atitudes de posicionamento político tanto de Benjamin quanto de Brecht. Talvez, é por semelhante posicionamento, que ambos propunham o texto da Crise e crítica como um empreendimento coletivo de produção intelectual crítico da sociedade capitalista. Assim, poder-se-ia muito bem conceber que ambos creditavam importância na figura do intelectual como figura pública, tornando-se então legítima uma atividade prática do intelectual ao lado da luta de classes. No entanto, partindo do reconhecimento da origem burguesa dos intelectuais, o projeto da revista se caracteriza como um veículo de difusão política da luta de classes e "não um órgão do proletariado." (BENJAMIN, 1985).

O que se revela como um empreendimento essencialmente político de posicionamento contra a sociedade capitalista, a Revista Crise e Crítica objetivava instruir e apresentar os elementos estruturais da sociedade capitalista do momento. Dito isso, estava no horizonte de expectativa dos autores que a revista se posicionasse como um órgão à disposição do proletariado. É importante, salientar que a ideia era um posicionamento de aproximação que, no entanto, não se confirmaria numa união orgânica. Benjamin e Brecht reconheciam que, mesmo sendo intelectuais de esquerda imbuídos de ideias revolucionárias, representavam no máximo um órgão do proletariado, porém, advindo da Intelligentsia burguesa. Estavam cientes, nesse sentido, do protagonismo do proletariado na luta de classes.

Pretendia-se, nesse sentido, fundar uma revista que atuasse na mediação entre os avanços da ciência reflexiva e as demandas articuladas do proletariado. Os intelectuais, como colaboradores, forneceriam uma certa expertise no que tange ao entendimento das "engrenagens da sociedade", como diria Brecht em seus ensaios sobre a prática teatral. Essas reflexões indicam um ponto de vista compartilhado entre 
Benjamin e Brecht no sentido da ideia de engajamento: os intelectuais que anseiam pela transformação devem se colocar à disposição dos anseios do proletariado sem, no entanto, eclipsarem as demandas intrínsecas dos explorados.

O papel da intelectualidade, seguindo o pensamento de Benjamin e Brecht, parte do princípio de que o comprometimento político nasce da necessidade de difundir o pensamento crítico na sociedade. Grandes excursões de um pensamento hermético têm importância reservada para discussões internas à academia. $O$ intelectual engajado realiza a transposição do pensamento fechado em si, traduzindo as questões essenciais da sociedade de forma didática. Para ficarmos com a ideia oferecida por Brecht, o artista, intelectual ou escritor, precisa ter ciência da função pedagógica de sua obra. Da mesma forma, um periódico científico de divulgação de conhecimento político, deve pressupor o caráter didático da sua constituição. As peças do teatro épico são exemplares dessa atitude.

Além disso, ao refletirem sobre a questão do engajamento intelectual, esses autores demonstraram a importância da formação de redes de colaboração política. Assim como no teatro épico o grande objetivo é promover um processo reflexivo que posteriormente irá transformação o espectador em colaborador, do ponto de vista da formação de um público crítico, a consolidação de redes de colaboração se mostrava para Benjamin e Brecht como essenciais para uma sociedade não-alienada. Por um lado, a questão perpassa pela transformação do papel dos intelectuais e dos artistas, por outro lado, elas dependem de inovações no próprio aparelho de difusão. $O$ conceito de intelectual engajado mobilizado no memorando da Revista é uma transposição das teses do teatro épico brechtiano. O teatro do herói surrado que traduz para o campo da estética os dilemas da luta de classes modernas representa um momento revigorado da postura de engajamento da arte e da ciência.

Segundo esse conceito de engajamento, uma postura de julgamento da sociedade deve se mostrar como incorruptível para artistas e intelectuais que visem a divulgação de um ponto de vista crítico. Num contexto de crise do capitalismo e, consequentemente, da sociedade burguesa, a proposição de um conceito de intelectualidade engajada se direciona contracorrente do status quo. A formulação do teatro épico de Brecht e a teoria do escritor progressista de Benjamin, concedem um retrato histórico da situação social dos períodos de 1920 e 1930 e a dissolução da 
ideia de imparcialidade dos intelectuais. O movimento sinérgico entre arte e política é representativo de um tratamento dialético oferecido à obra de arte, dessa vez, reunindo elementos do conjunto das relações sociais de produção com as reflexões necessárias para a transformação da sociedade atual. Portanto, a arte engajada se define pela capacidade de desvelamento das contradições sociais e pela produção de uma rica experiência de aprendizado. Os problemas das contradições de classes são esclarecidos num processo reflexivo de transformação.

É assim, em todo caso, que as propostas de engajamento da arte estão apresentadas na proposta do teatro épico de Brecht e retomadas e retrabalhadas teoricamente por Benjamin. O artista ou intelectual que dirige seus esforços para a criação de uma sociedade melhor municia-se, para os pensadores apresentados aqui, tanto de uma leitura posicionada da filosofia como da arte. Eles estão, como Benjamin lembra das teses Sobre o Conceito de história, na contracorrente do conformismo, isto é, conseguem articular o pensamento para transformar a sociedade, mas, para isso, dependem de uma transformação anterior: o leitor, a plateia, a massa, devem se tornar, antes de mais nada, em pensadores.

O pensar criticamente, posto em perigo diante dos problemas alienação moderna, foi mobilizado como ponto central para a reflexão estética e filosófica de Brecht e Benjamin. Cada autor, à sua forma, colocou a questão da transformação da sociedade sob o prisma do vínculo entre pensamento mediado pela dialética e atuação prática política. Esse eixo central é potencializado por uma atitude crítica herdada do marxismo. Conceitos centrais oriundos dessa tradição de pensamento como conjunto de relações sociais vivas, desvelamento das engrenagens da sociedade, crítica à sociedade atual, reconhecimento das conexões entre indivíduos e coletividade e a própria noção de crítica imanente presumem um conceito enfático de totalidade, atuam de forma fundamental na execução de exercícios de crítica na obra de Brecht e Benjamin.

\section{REFERÊNCIAS}

ADORNO, Theodor. Commitment. New Left Review. I/87-88, September-December. London. 1974 [1962], pp. 75-89.

Doutorando em Sociologia pela Universidade de Brasília - UnB. Brasileiro, residente em Brasília. 
Correspondência, 1928-1940. Theodor W. Adorno, Walter Benjamin. São Paulo: Editora Unesp, 2012.

ARISTÓTELES, 384-322 A.C. Poética. Editora Cultrix: São Paulo. 1985.

BENJAMIN, Walter. The correspondence of Walter Benjamin, 1910-1940. University of Chicago Press. 1994.

. Walter Benjamin's Archive: images, texts, signs. Londres: Verso Books, 2015.

. Memorandum zu der Zeitschrift 'Krisis und Kritik'. In__: Gesammelte Schriften VI. Frankfurt am Main: Suhrkamp, 1985, pp. 619-622.

A obra de arte na era de sua reprodutibilidade técnica. In__: Obras escolhidas. Vol. 1. Magia e técnica, arte e política: ensaios sobre literatura e história da cultura. São Paulo: Brasiliense, 1987, pp. 165-196.

. Sobre o conceito de história. In__: Obras escolhidas. Vol. I. Magia e técnica, arte e política. Ensaios sobre literatura e história da cultura. São Paulo: Brasiliense, 1987, pp. 222-234.

. Ensaios sobre Brecht. São Paulo: Boitempo, 2017.

. A Asja Lacis. In_ _ Materiales para un autorretrato. 1ํㅡㄹ ed. Ciudad Autónoma de Buenos Aires: Fondo de Cultura Económica, 2017.

BRECHT, Bertolt. Diário de trabalho, volume I: 1938-1941. Rio de Janeiro: Editora Rocco, 2002.

Estudos sobre teatro. Rio de Janeiro: Nova Fronteira, 1978.

. Teatro dialético (ensaios). Rio de Janeiro: Editora Civilização Brasileira, 1967.

. Um homem é um homem. In__: Bertolt Brecht, teatro completo II. Rio de Janeiro: Paz e Terra, 1987, pp.145-218.

. A mãe. In_: Bertolt Brecht, teatro complete Volume IV. Rio de Janeiro: Paz e Terra, 1990, pp. 161-236. 
. Poemas 1913-1956. São Paulo: Editora 34, 2012.

de CARVALHO, Sérgio. Brecht e a polêmica sobre o Expressionismo. Marx e o Marxismo. V.3, n.5, Jul/Dez. 2015.

EWEN, Frederic. Bertolt Brecht - His life, his art, and his times. The Citadel Press, New York. 1969

KONDER, Leandro. Benjamin e o marxismo. ALEA: Estudos Neolatinos. Vol. 5, N, 2, Rio de Janeiro. 2003.

A poesia de Brecht e a história. Instituto de Estudos Avançados da Universidade de São Paulo. 1996.

LUKÁCS, Georg. História e consciência de classe: estudos sobre a dialética marxista. 3ํe edição. São Paulo: Editora Martins Fontes, 2018.

SANTOS, W.B. A crise do capitalismo em cena: notas sobre a obra Santa Joana dos Matadouros, de Bertolt Brecht. Dramaturgia em foco, Petrolina-PE, v.2, n.2, p.19-39, 2018.

. O pensamento indisciplinado de Walter Benjamin: teoria crítica, messianismo judaico e teatro épico nos escritos de 1930 a 1940. 2018. 201 f. Dissertação (mestrado em sociologia). Universidade de Brasília, Brasília, 2018.

WIZISLA, Erdmut. Benjamin y Brecht: historia de una Amistad. Buenos Aires: Paidós, 2007. 